\title{
Tongue of Laughing Dove (Stigmatopelia senegalensis): Histochemical and Ultrastructural Characteristics
}

\section{Farouk $\mathrm{SM}^{1 *}$ and Hassan $\mathrm{SA}^{2}$}

${ }^{1}$ Department of Cytology and Histology, Suez Canal University, Ismailia 41522, Egypt

${ }^{2}$ Department of Anatomy and Embryology, Suez Canal University, Ismailia 41522, Egypt

\begin{abstract}
This study examined the morphology and histology of the adult laughing dove tongue from birds of both sexes and compared the results those reported in the literature concerning other bird species. The tongue of the adult laughing dove has an elongated triangular shape and a median groove. Both dorsal and ventral lingual surfaces were covered by keratinized stratified squamous epithelium, which decreased in thickness and degree of keratinization, when progressing toward the root. The dorsal surface of the lingual apex and body showed desquamated epithelial cells with differences in size, shape and appearance of these cells according to their location on the tongue. The openings of lingual glands were observed on the ventrolateral surface of the caudal half of the body of the tongue. A narrow rim of fibrous connective tissue beneath the epithelium surrounding the central lingual core was composed of a single cartilaginous plate and skeletal muscle bundles. Large conical papillae were located symmetrically between the body and root of the tongue. An additional row of conical papillae were located behind the previously mentioned row. The ventral aspect of the tongue was free from any papillae but had numerous shallow folds in addition to a row of three openings for lingual salivary glands.
\end{abstract}

Keywords: Histochemistry; Scanning Electron Microscopy; Tongue; Lingual glands; Laughing dove

\section{Introduction}

The Laughing Dove belongs to the family columbidae, genus spilopelia [1], and is found to reside in Sub-Saharan Africa, Arabia, Iran, Iraq, Afghanistan, Pakistan and India [2,3]. These birds feed on seeds, grasses, other vegetable matter and small ground insects such as termites and beetles $[4,5]$.

All birds adapt to their different environments with respect to food sources. Reflecting their different lifestyles, birds have different feeding habits, with corresponding differences in the structures of their tongues with the shape and structure of the tongue differing according to the type of food and method of food intake [6,7]. Macroscopically, the tongue is triangular and elongated in many birds $[8,9]$ and three parts of the tongue may be distinguished: apex, body and root. The body and the root of the tongue are demarcated externally by a single or double crest of mechanical conical papillae $[10,11]$. Morphological and functional study of various avian species indicated a close relationship between the histological structure of the tongue with the feeding habits of the particular bird species $[10,12,13]$.

Studies on tongue morphology, especially the structure of the dorsal surface have been carried out in a small number of avian species such as the golden eagle [14]; woodpecker [13]; cormorant [15]; ostrich [16]; falcon and kestrel [17]; owl [12]; white tailed eagle [7] and little tern [18]. Many authors have described the structure of the lingual mucosa, type and distribution of mechanical papillae and the degree of keratinization of the lingual epithelium $[19,20]$. The results of morphological studies conducted so far indicated a close correlation of the shape of the tongue with the method of food intake and the type of food and habitat. In the available literature, there is little histochemical characterization of the tongue or the lingual glands. The purpose of this study was, therefore, to describe histochemically and morphologically the tongue of the laughing dove in addition to comparing the results with previous data from other birds obtained from the literature.

\section{Material and Methods}

Sex adult doves ( $\pm 95 \mathrm{~g})$ (1-2 years old) were collected from wild bird hunters in Damietta governorate, Egypt. Species identification and age determination were adopted according to Klos and Lang [21]. Birds were anaesthetized by i.m. injection of $0.5 \mathrm{cc}$ of $2 \%$ xylazine $\mathrm{Hcl}(3 \mathrm{mg} /$ $\mathrm{kg}$ ), followed by i.v. injection of heparin (Cal Heparin, 5000 I.U.) in the wing vein to prevent blood clotting. The birds were then decapitated, the whole tongue with the surrounding tissues were removed from each bird. Half of each tongue was used for scanning electron microscopy and five halves were processed for histological and histochemical studies. This study was approved by the scientific research ethics committee, faculty of veterinary medicine, Suez Canal University. All procedures were approved by the Suez Canal University Animal Use Committee and carried out in accordance with the National Institutes of Health Guide for the Care and Use of Laboratory Animals (National Institutes of Health Publication No. 85-23, revised 1996).

\section{Tissue processing for histological and histochemical investigations}

The five half tongues were cut into three parts; apex, body and root then immersed directly in $10 \%$ neutral buffered formalin. Following good fixation of the specimens for at least one week in refrigerator, the formalin-fixed specimens were preserved in $70 \%$ ethyl alcohol in refrigerator. The preserved samples were dehydrated using a graded

*Corresponding author: Farouk SM, Department of Cytology and Histology, Faculty of Veterinary Medicine, Suez Canal University, Ismailia 41522, Egypt, Tel: 002-01098395384; Fax: 002-064-3207052; E-mail: dr_smf hist@yahoo.com; dr_smf_hist@vet.suez.edu.eg

Received August 03, 2015; Accepted August 24, 2015; Published August 26, 2015.

Citation: Farouk SM, Hassan SA (2015) Tongue of Laughing Dove (Stigmatopelia senegalensis): Histochemical and Ultrastructural Characteristics. J Cytol Histol 6: 363. doi:10.4172/2157-7099.1000363

Copyright: (C) 2015 Farouk SM, et al. This is an open-access article distributed under the terms of the Creative Commons Attribution License, which permits unrestricted use, distribution, and reproduction in any medium, provided the original author and source are credited. 
Citation: Farouk SM, Hassan SA (2015) Tongue of Laughing Dove (Stigmatopelia senegalensis): Histochemical and Ultrastructural Characteristics. J Cytol Histol 6: 363. doi:10.4172/2157-7099.1000363

series of ethyl alcohol $(75 \%, 80 \%, 90 \%, 95 \%, 3$ changes of absolute ethyl alcohol ), subjected to three changes of xylene, then embedded in paraffin wax. The paraffin-embedded specimens were serially sectioned at $5-7 \mu \mathrm{m}$ thickness. The paraffin sections were subjected to the following stains: Harris hematoxylin and eosin (H\&E), Masson's trichrome, Periodic-Acid Schiff (PAS) and Alcian blue according to Bancroft and Stevens [22].

\section{Tissue processing for scanning electron microscopy (SEM)}

The half tongues were quickly rinsed with $0.1 \mathrm{M}$ phosphate buffer at $\mathrm{pH} 7.3$ then immersed in $10 \%$ buffered paraformaldehyde buffer $(\mathrm{pH}$ 7.2) and stored at $4^{\circ} \mathrm{C}$ until processed for scanning electron microscopy. Post fixation of the samples was made in $1 \%$ osmium tetroxide solution in water for two hours then each half tongue was dehydrated through ascending graded ethyl alcohol series (70\%, 80\%, 90\%, 95\%, 99\%, $100 \%)$ for five minutes in each concentration then infiltrated with hexamethyl disilazane (HMDS), followed by critical point drying under carbon dioxide. The dried specimens were mounted on aluminum stubs covered with carbon tabs, and were sputter-coated with goldpalladinum before being examined by JEOL-5400 LV scanning electron microscope.

\section{Photomicroscopy}

The collected images for histological and histochemical investigations were taken using Olympus BX41 research optical photomicroscope fitted with an Olympus DP25 digital camera. Photomicrographs for ultrastructural examination were observed at various angles under the scanning electron microscope (stereoscan 360, Leica Cambridge Ltd., England) at an accelerating voltage of $15 \mathrm{kV}$.

\section{Morphometrical measurements}

The thickness of the lingual epithelium on both the lingual dorsal and ventral aspects of the tongue was measured and compared. For these quantitative measurements, three slides (one for apex, one for body, one for root) from each of the five tongues. For each slide, the average of at least three measurements of lingual epithelial thickness from each of the different parts of the tongue were measured.

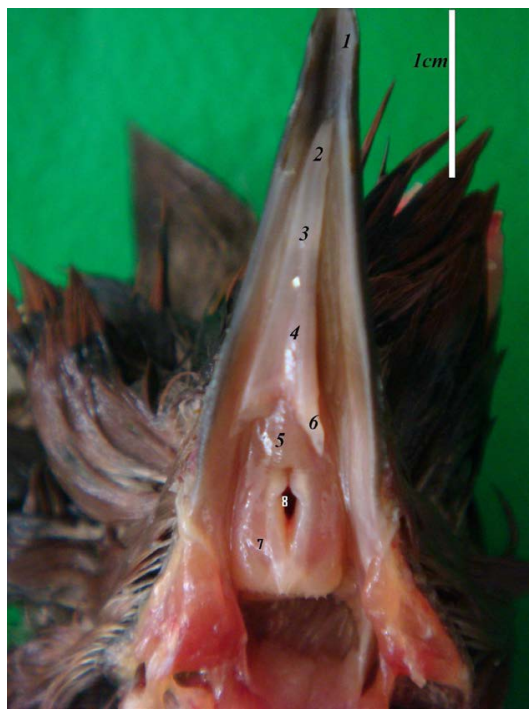

Figure 1: Photomicrograph of the tongue of the laughing dove:1- Rostrum mandibulare, 2- apex linguae, 3- Corpus linguae, 4- median groove, 5Radixlinguae, 6- Horny papillae, 7- laryngeal mound, 8- glottis.

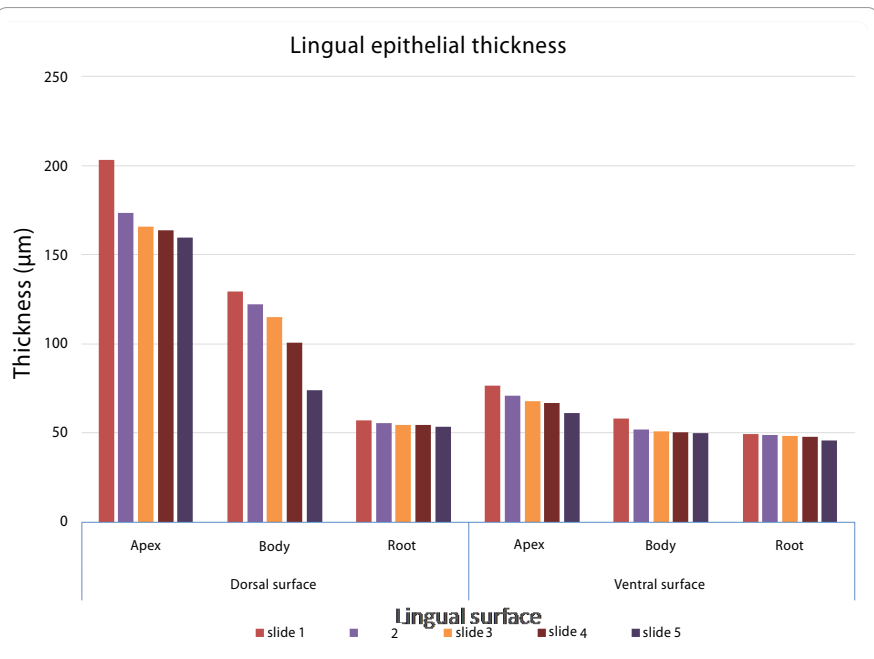

Figure 2: Graph showing the average thickness $(\mu \mathrm{m})$ of the lingual epithelium in successive parts of the tongue; apex, body and root.

The magnification scale bars reported on the photomicrographs and the quantitative measurements of lingual epithelial thicknesses were determined with the aid of digitized calibration software in the image analysis program that was used (Olympus CellSens, ver. 1.5).

\section{Statistical analysis}

All measurements were statistically analyzed by Pearson's correlation coefficient according to Cohen [23] the statistical Package for Social Science (SPSS) software program, version 16.0 [24].

\section{Results}

\section{Macroscopic investigation}

The adult laughing dove tongue has an elongated triangular shape with a pointed tip (Figure 1). The length of the tongue was about $17 \mathrm{~mm}$ while the bill was about $24 \mathrm{~mm}$, so the tongue occupied about $70.8 \%$ of the bill length.

\section{Histological and histochemical observation}

Each part of the tongue, apex, body and root was lined on the dorsal and ventral surfaces with stratified squamous epithelium varying in keratinization and characterized by considerable decrease in thickness toward the root (Figure 2).

Histological investigation of the tongue revealed that the dorsal surface of the apex was lined by slightly keratinized stratified squamous epithelium composed of $6-8$ layers of polyhedral cells covered by a few layers of keratinized epithelial cells while the ventral surface with thinner but was highly keratinized and also possessed a slightly wavy basement membrane (Figure 3). A central hyaline cartilage plate was supported by longitudinally oriented skeletal muscle fibers. These muscle fibers extended into the core of the tongue from the apex and were surrounded by a narrow region of collagenous fibers and lamina propria (Figure 3). The dorsal epithelium of the tongue was thrown into a median invagination along the longitudinal axis of the tongue without any change to the underlying connective tissue (Figure 3).

The lingual body had the same general structure as the apex but with a few differences. A pronounced decrease in the thickness of dorsal and ventral epithelial surfaces was noticed (Figure 2) as well as the degree of keratinization of the epithelial lining of both surfaces (Figure 4). The 
Citation: Farouk SM, Hassan SA (2015) Tongue of Laughing Dove (Stigmatopelia senegalensis): Histochemical and Ultrastructural Characteristics. J Cytol Histol 6: 363. doi:10.4172/2157-7099.1000363

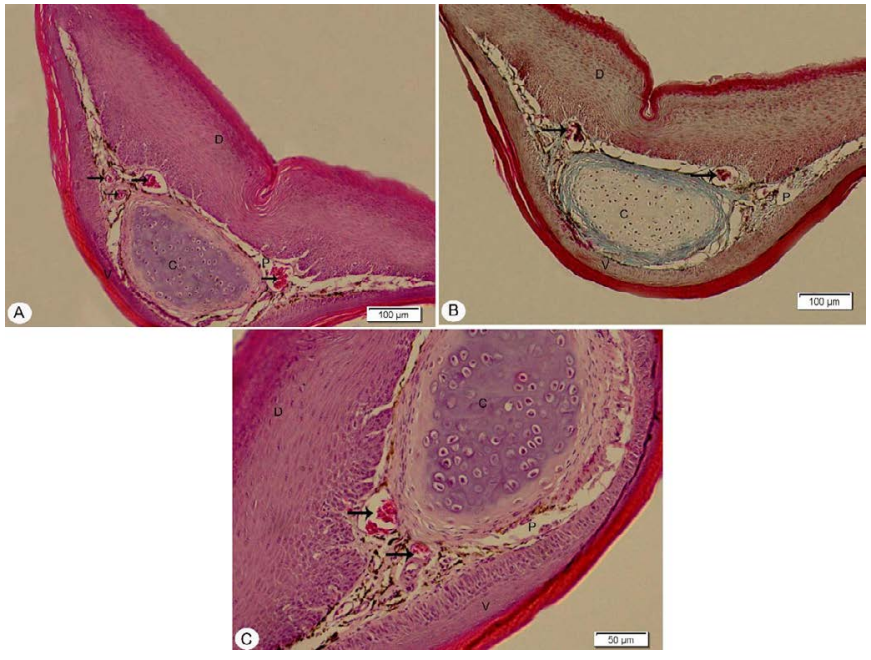

Figure 3: Photomicrograph of a transverse section of the tongue apex showing the slightly keratinized dorsal surface $(D)$, lamina propria $(P)$, skeletal muscle fibers (arrows), highly keratinized ventral surface (V), cartilaginous plate (C) ,surrounded by large amount of collagenous fibers. A; H\&E stain, B; Masson's trichrome, $\mathrm{C}$; high magnification of $\mathrm{A}$.

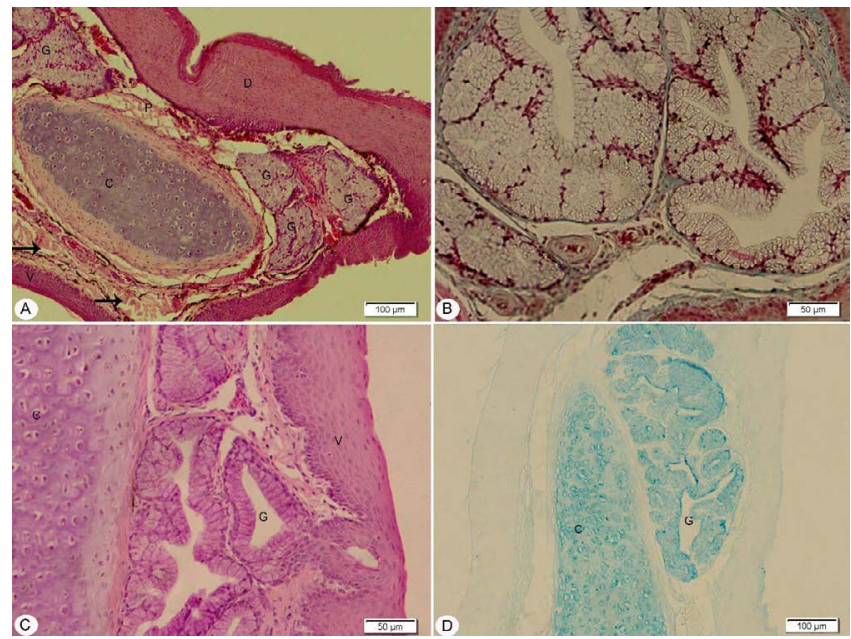

Figure 4: Photomicrograph of transverse and longitudinal sections of the tongue body showing slightly keratinized dorsal surface (D), lamina propria $(P)$, Faint PAS and strongly alcianophilic positive reactive tubuloaveolar lingual glands $(G)$, skeletal muscle fibers (arrows), slightly keratinized ventral surface (V), Alcianophilic cartilaginous plate (C). A; H\&E stain, B; Masson's trichrome, C; PAS, D; Alcian blue.

lingual glands were visible in the body lateral to the centrally located Alcianophilic cartilaginous plate (Figure 4). These glands were of the tubuloalveolar type, lined by high cuboidal to columnar cells with faintly eosinophilic, PAS positive and strongly alcianophilic cytoplasm and surrounded by appreciable amount of collagen fibers (Figure 4). Based on successive serial sections we observed that the lingual glands were directed toward the ventral surface of the tongue below the cartilaginous plate (Figure 4).

At the lingual root, the dorsal and ventral epithelium showed a marked decrease in thickness (Figure 2) as well as in the degree of keratinization (Figure 5). The central core of the lingual body comprised longitudinally and transversally oriented skeletal muscle fibers surrounded the cartilaginous core (Figure 5). The lingual glands were located beneath the cartilaginous palate and their ducts opened into the ventral surface especially in the caudal one third of the lingual body (Figure 5). The end of the lingual body was detected by the presence of highly keratinized conical papillae directed backward from the dorsal surface that separated the lingual body from the root (Figure 5 ). The dorsal and ventral surface of the lingual root became covered by non-keratinized stratified squamous epithelium. The root contained large numbers of tubuloalveolar lingual glands, which filled most of the volume of the lingual root (Figure 5).

Concerning the lingual epithelial thickness, the quantitative measurements throughout the randomly selected specimens demonstrated that there was a progressive decrease in the thickness at both the dorsal and ventral surfaces. Statistical analysis revealed a highly significant, positive correlation between the thickness of the dorsal surface of the tongue apex and that of the tongue root, but there was no correlation between the thickness of dorsal surface of the tongue apex and that of body. Finally there was a significant correlation between the epithelial thickness of the dorsal surface of body and that of root. Also statistical analysis revealed a highly significant, positive correlation between the thickness of the ventral surface of the tongue apex and that of root, and there was significant correlation between the thickness of the ventral surface of the tongue apex and that of body, but there was no correlation between the thickness of the ventral surface of the tongue body and the root (Figure 2 and Table 1).

\section{Scanning electron microscopy}

A median groove was observed on the dorsal lingual surface of the apex and body of the tongue. The groove divided the apex and body of the tongue into two symmetrical halves (Figures 1 and 6). Large conical papillae were located symmetrically in the form of the letter $\mathrm{V}$ between the body and root of the tongue (Figures 6 and 7). Approaching the midline of the tongue, the papillae, gradually become shorter and more slender (Figure 7). An additional row, composed only of two larger papillae for each half, was observed behind the main row of papillae (Figure 6). Apices of the lingual papillae were pointed towards the posterior part of the tongue (Figure 6).

SEM images showed that superficial keratinized epithelial cells were exfoliated as isolated squamous cells. There were differences in the

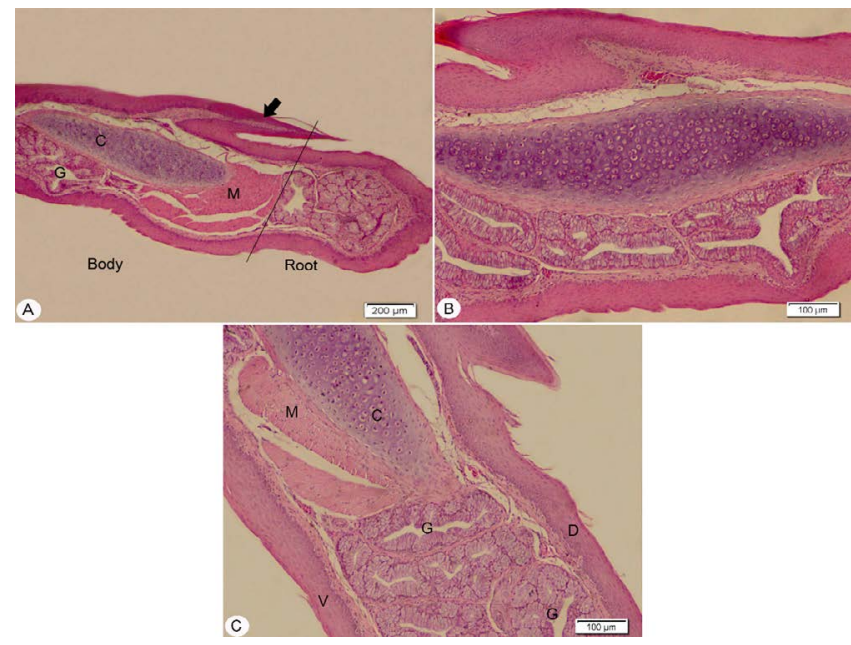

Figure 5: Photomicrograph of longitudinal H\&E stained sections of the tongue body and root showing highly keratinized horny papilla (arrow), lingual glands $(G)$, skeletal muscle fibers $(M)$, non-keratinized dorsal $(D)$ and ventral surface $(V)$, cartilaginous plate $(C)$. 
Citation: Farouk SM, Hassan SA (2015) Tongue of Laughing Dove (Stigmatopelia senegalensis): Histochemical and Ultrastructural Characteristics. J Cytol Histol 6: 363. doi:10.4172/2157-7099.1000363

\begin{tabular}{|c|c|c|c|c|c|c|c|}
\hline & & \multicolumn{3}{|c|}{ Dorsal surface } & \multicolumn{3}{|c|}{ Ventral surface } \\
\hline & & Apex & Body & Root & Apex & Body & Root \\
\hline \multirow{3}{*}{ 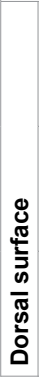 } & $\begin{array}{l}\text { Apex Pearson } \\
\text { Correlation } \\
\text { Sig. (2-tailed) } \\
\mathrm{N}\end{array}$ & ---- & $\begin{array}{c}0.729 \\
0.162 \\
5\end{array}$ & $\begin{array}{c}0.963^{* *} \\
0.009 \\
5\end{array}$ & $\begin{array}{c}0.917^{*} \\
0.028 \\
5\end{array}$ & --- & --- \\
\hline & $\begin{array}{l}\text { Body Pearson } \\
\text { Correlation } \\
\text { Sig. (2-tailed) } \\
\text { N }\end{array}$ & $\begin{array}{c}0.729 \\
0.162 \\
5\end{array}$ & ---- & $\begin{array}{c}0.882^{*} \\
0.048 \\
5\end{array}$ & ---- & $\begin{array}{c}0.688 \\
0.199 \\
5\end{array}$ & --- \\
\hline & $\begin{array}{l}\text { Root Pearson } \\
\text { Correlation } \\
\text { Sig. (2-tailed) } \\
\text { N }\end{array}$ & $\begin{array}{c}0.963^{\star *} \\
0.009 \\
5\end{array}$ & $\begin{array}{c}0.882^{*} \\
0.048 \\
5\end{array}$ & --- & --- & --- & $\begin{array}{c}0.922^{*} \\
0.026 \\
5\end{array}$ \\
\hline \multirow{3}{*}{ 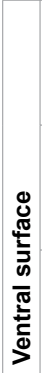 } & $\begin{array}{l}\text { Apex Pearson } \\
\text { Correlation } \\
\text { Sig. (2-tailed) } \\
\mathrm{N}\end{array}$ & $\begin{array}{c}0.917^{*} \\
0.028 \\
5\end{array}$ & ---- & ---- & ---- & $\begin{array}{c}0.890^{*} \\
0.043 \\
5\end{array}$ & $\begin{array}{c}0.965^{\star *} \\
0.008 \\
5\end{array}$ \\
\hline & $\begin{array}{l}\text { Body Pearson } \\
\text { Correlation } \\
\text { Sig. (2-tailed) } \\
\text { N }\end{array}$ & ---- & $\begin{array}{c}0.688 \\
0.199 \\
5\end{array}$ & ---- & $\begin{array}{c}0.890^{*} \\
0.043 \\
5\end{array}$ & --- & $\begin{array}{c}0.747 \\
0.147 \\
5\end{array}$ \\
\hline & $\begin{array}{l}\text { Root Pearson } \\
\text { Correlation } \\
\text { Sig. (2-tailed) } \\
\text { N }\end{array}$ & --- & --- & $\begin{array}{c}0.922^{*} \\
0.026 \\
5\end{array}$ & $\begin{array}{c}0.965^{\star *} \\
0.008 \\
5\end{array}$ & $\begin{array}{c}0.747 \\
0.147 \\
5\end{array}$ & --- \\
\hline
\end{tabular}

Table 1: Correlation matrix of lingual epithelial thicknesses.

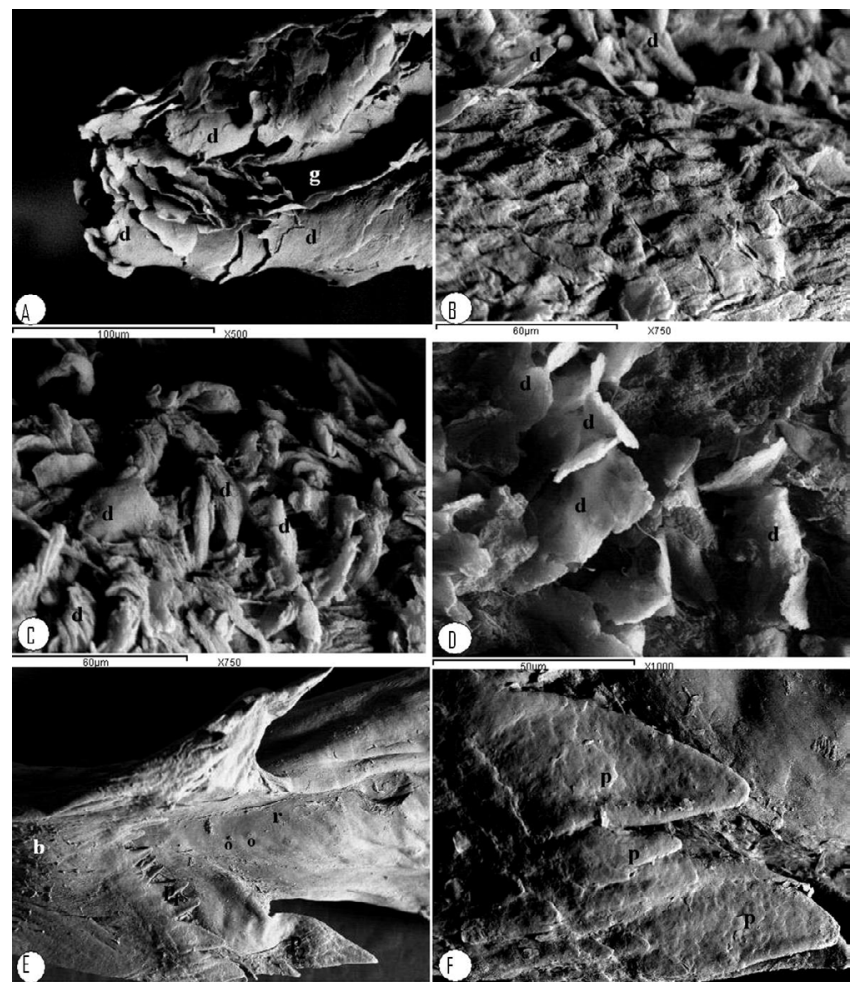

Figure 6: Scanning electron micrograph of the dorsal surface of the tongue: A- apex, B, C and D- the rostral middle and caudal third of lingual body, E, Fbody and root, disquamated cells (d) leave-like at the apex and caudal third of tongue body while it is tap-like at the rostral and middle third of the tongue body, The central longitudinal groove (g), V- shaped row conical papillae between the body and the root of tongue ( $\mathrm{p} 1$ ), additional row composed only of two larger papillae in each half behind the main row of papillae (p2), Root of tongue ( $r$ ), corpus lingue (b) and Openings of the lingual slivary glands (o), larger peripherally located conical papillae located in the v- shaped row between the root and body of the tongue $(p)$.

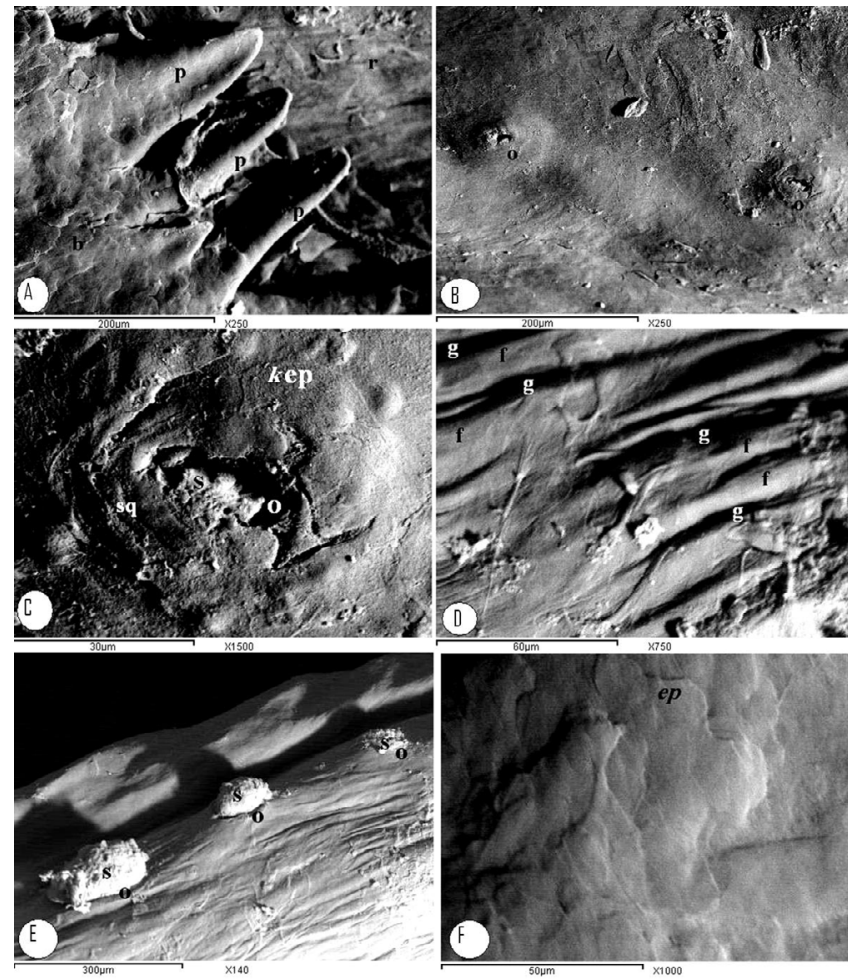

Figure 7: Scanning electron micrograph of the dorsal $(A-C)$ and ventral (D-F) surface of the tongue: A- body and root, B, C - root of the tongue, D, E- ventral surface of the body, $\mathrm{F}$ - tongue root, smaller medially located conical papillae $(p)$ in the $v$ - shaped row (b), elongated openings of the lingual salivary glands (o), Keratinized epithelium (kep), secretion (s), concentrically arranged epithelial cells (sq), longitudinal microridges (f) separated by longitudinal microgrooves (g), smooth non-keratinized epithelial surface (ep).

size, shape and appearance of these cells according to their location on the tongue. The cells were highly keratinized leaf-like cells on the apex and caudal thirds of the body of the tongue (Figure 6). The rostral and middle thirds of the tongue presented less keratinized, square-shaped desquamated cells in addition to few leaf-like cells (Figure 6). The dorsal and ventral surfaces of the lingual root presented a smooth surface with no desquamated cells, but the elliptical openings of lingual salivary glands were found and numbered about seven openings per cubic $\mathrm{mm}$ (Figure 7). The ventrolateral surface of the caudal half of the tongue body showed about three openings for lingual salivary glands on each side. These openings appeared to be filled with glandular secretions, which seemed to be mixture of neutral and acidic mucopolysaccharides (Figures 4 and 7). In addition to these openings on the ventral surface of the tongue, there were numerous short longitudinal microridges separated by moderate microgrooves (Figure 7).

\section{Discussion}

The present study showed that the tongue of the laughing dove, like many other birds, has an elongated triangular shape and fills the lower part of the bill. The tongue shape in birds is a species specific [10,25]. The different shapes in tongue form in avian is described in Table 2.

The dorsal and ventral lingual surfaces of the laughing dove are covered by stratified squamous keratinized epithelium especially at the apex, but without the presence of any lingual papillae. These observations were similar to those described by for the Little Egret, except the presence of some backward pointed filiform papillae on 
Citation: Farouk SM, Hassan SA (2015) Tongue of Laughing Dove (Stigmatopelia senegalensis): Histochemical and Ultrastructural Characteristics. J Cytol Histol 6: 363. doi:10.4172/2157-7099.1000363

\begin{tabular}{|l|l|l|}
\hline Tongue shape & birds & authors \\
\hline Triangular & Most species & $\begin{array}{l}\text { Vollmerhaus and Sinowatz [10], Parchami } \\
\text { et al. [14], McLelland [30], McLelland [33] } \\
\text { and Grant and Temeles [35] }\end{array}$ \\
\hline Elongated tubular & $\begin{array}{l}\text { hummingbirds, } \\
\text { sunnybirds and } \\
\text { woodpeckers }\end{array}$ & Campbell and Lack [25] and Iwasaki [36]. \\
\hline Elongated flat & $\begin{array}{l}\text { water fowl, such } \\
\text { as geese and } \\
\text { ducks }\end{array}$ & $\begin{array}{l}\text { Vollmerhaus and Sinowatz [10], Iwasaki } \\
\text { and Kobayashi [19] and Iwasaki et al.[36]. }\end{array}$ \\
\hline Very small & $\begin{array}{l}\text { some fish eating } \\
\text { birds such as } \\
\text { pelicans and } \\
\text { cormorants }\end{array}$ & Campbell and Lack [25]. \\
\hline $\begin{array}{l}\text { small mushroom- } \\
\text { shaped }\end{array}$ & $\begin{array}{l}\text { cormorant } \\
\text { Cackowiak et al.[15]. }\end{array}$ \\
\hline
\end{tabular}

Table 2: Deferent shapes of tongue in avian species.

\begin{tabular}{|l|l|l|}
\hline $\begin{array}{l}\text { Dorsal surface } \\
\text { of tongue }\end{array}$ & Birds & authors \\
\hline Median groove & $\begin{array}{l}\text { Golden eagle, } \\
\text { white tailed } \\
\text { eagle, ducks } \\
\text { and geese }\end{array}$ & $\begin{array}{l}\text { Jackowiak and Godynicki [7], Vollmerhaus } \\
\text { and Sinowatz [10], Komarek [11] and } \\
\text { Parchami [14]. }\end{array}$ \\
\hline Median crest & cormorant & Jackowiak et al. [15] \\
\hline $\begin{array}{l}\text { No marked } \\
\text { structure }\end{array}$ & Most birds & $\begin{array}{l}\text { Kobayashi et al. [6], Emura [26], McLelland } \\
\text { [30] and Grant and Temeles [35]. }\end{array}$ \\
\hline
\end{tabular}

Table 3: Dorsal lingual surfaces between different avian species.

its dorsal surface. On the other hand, it has been stated that dorsal lingual surface of the laughing dove was covered by a multilayered non-keratinized stratified squamous epithelium, while the ventral and lateral surfaces of the tongue was covered with keratinized stratified squamous epithelium.

The present study showed that the lingual body was separated from the root by a transverse row of posteriorly directed, large, conical papillae. Also there was an additional row of two to three larger papillae on each side behind the previously mentioned row. In the marginal region between the anterior and posterior parts of the tongue of the chicken, a close array of giant conical papillae was observed, arranged transversely in a row [26]. At a point approximately $2 / 3$ of the length of the tongue in the golden eagle, white tailed eagle, black kite, northern goshawk and between the body and the root of the tongue there were large conical papillae, the apices of which also were pointed posteriorly [7,27-29]. In the tongues of the peregrine falcon, common kestrel and owl the region of conical papillae between the lingual apex and lingual root is very wide area $[12,17]$. In the Japanese Pygmy Woodpecker and ostrich, large conical papillae were not observed between the lingual body and root $[13,16]$. The distribution of these lingual papillae appears to be related to the eating habits of the bird species. The conical papillae found on the lingual body aid in transfer of swallowed food towards the oesophagus and prevent its regurgitation [7].

The present study revealed that the mucosa of both dorsal and ventral lingual surfaces in the laughing dove was covered by keratinized epithelium and this epithelium was desquamated on the dorsal surface of the lingual apex and body. In most avian species, the whole dorsal surface of the tongue up to the conical papillae is covered by keratinized stratified squamous epithelium, whereas the non-cornified stratified epithelium usually covers a part of the root of the tongue [26,30,31]. The current study revealed the presence of longitudinal microridges on the ventral surface of the body of the tongue. These microridges also have been described for the tongues of both mammals and birds. The microridges have been interpreted as structures that increase adhesion of mucus to the epithelium $[18,32]$.
The lingual epithelium was thicker at the tongue apex and a marked gradual decrease in thickness was observed toward the root of the tongue. The core of the tongue contained lamina propria, a central cartilaginous plate, muscle fibers and lingual glands. The greater thickness and keratinization of the lingual epithelium might enable the bird to tolerate injuries from consuming hard grains during feeding. This possibility was supported by Jackowiak and Ludwing [16] who mentioned that the thickness of lingual epithelium and keratinized layer of birds differ according to the type of food intake.

It has been reported the tongue of the dove is supported by paraglossum, which is a single, cartilage oval rod running through the apex of the tongue but is double in the body of the tongue. This finding was similar to that observed in our work except that we observed a single, centrally located hyaline cartilaginous plate that invaded the lingual core from the apex to the end of body region.

Our findings showed topographical differences in the size, shape and appearance of desquamating cells of the surface lingual epithelium. Cells were leaf-like on the apex and caudal third of the lingual body and square-shaped on the rostral and middle thirds of the body of the tongue. It has been reported that the tongue apex showed thick plates that overlapped with each other and were separated by clear fissures; and at the posterior part of the tongue, the epithelium was covered with a smooth slightly folded layer. The observed shape differences between desquamating cells of these regions may be due to the variability in microabrasion patterns. This high degree of keratinization and desquamation should be related to the nature of the food that the laughing dove eats, namely dry seed and grasses. Topographical differences in the size, shape and appearance of the desquamating cells of the dorsal lingual epithelium also were noted for the tongue of common quail [14]. The current study revealed that there was a distinct median groove that divided the apex and body of the tongue into two symmetrical halves. The differences in the dorsal surface of the tongue in avian species are described in Table 3.

The lingual glands, observed in the body region of the tongue, were of the tubuloalveolar type and lined by high cuboidal to columnar cells with faintly eosinophilic cytoplasm surrounded by appreciable amount of collagenic fibers which directed toward the ventral surface of the tongue below the cartilaginous plate. The lingual glands are of the tubuloalveolar type and located beneath the dorsal lingual epithelium and lined with connective tissue, their ducts opened onto the dorsal surface of the tongue. McLelland [33] mentioned that the structure of lingual glands is more developed and complex in birds that feed on dry food compared to those consuming naturally well-lubricated food. Our investigation of the histochemistry of the lingual glands emphasized the presence of well-developed positive PAS reactive and Alcianophilic lingual gland. In some species of birds there are anterior and posterior lingual glands $[10,27,30,33]$. The orifices of the anterior lingual glands found on the edges of the lingual body or occasionally on the lateral surfaces of the tongue, but the orifices of the posterior lingual glands are located on the dorsal surface of the root of the tongue. However, the present study indicated that, in the laughing dove, the anterior group was found on the ventrolateral side of the caudal third of the lingual body while the posterior group was located on the dorsal surface of the root of the tongue. El-Bakary [34] reported that the anterior lingual glands of the hoopoe were located on the entire tongue body and the posterior lingual glands were located on the entire tongue root. Jackowiak and Godynicki [7] indicated that secretions from these lingual glands was collected in the subepithelial chamber with the wide orifices, and then was effectively evacuated to the surface of the tongue. 
Citation: Farouk SM, Hassan SA (2015) Tongue of Laughing Dove (Stigmatopelia senegalensis): Histochemical and Ultrastructural Characteristics. J Cytol Histol 6: 363. doi:10.4172/2157-7099.1000363

Our results showed that no lingual papillae were seen on the lingual root. Similar SEM findings have been reported on the lingual root of the golden eagle, owl and white tailed eagle $[7,12,29]$. In the Japanese Pygmy Woodpecker, needle-like processes were observed on the dorsal surface of the lingual root [13]. The current study showed that the tongue in the laughing dove had an additional row of conical papillae, composed only of two large papillae in each half, located behind the main row of papillae.

In conclusion, the tongue of the laughing dove shows many similarities to tongues of other avian species. The most important difference reported in this study between the laughing dove and other birds is the presence of openings of the rostral lingual salivary glands on the ventrolateral side of the lingual body, which contained a mixture of neutral and acidic mucopolysaccharides. Also there was a close relation between the nature of the food consumed and the degree of desquamation of lingual epithelium in that the lingual epithelium in the laughing dove shows a high degree of desquamation in the dorsal surface of the apex and body due to consumption of dry and rough seeds.

\section{References}

1. Cheke S (2005) Naming segregates from the Columba-Streptopelia pigeons following DNA studies on phylogeny. Bulletin of the British Ornithologists' Club 125: 293-295.

2. Ali S, Ripley SD (1981) Handbook of the Birds of India and Pakistan. (2ndedn), New Delhi: Oxford University Press 3: 155-157.

3. Ticehurst CB (1923) The Birds of Sind. (Part V) Ibis 65: 438-473.

4. Satheesan SM, Prakash Rao, Datye H (1990) Biometrics and food of some doves of the genus Streptopelia. Journal of the Bombay Natural History Society 87: 452-453

5. Adang KL, Ezealor AU, Abdu PA, Yoriyo KP, (2008) Food habits of four sympatric columbids (Aves: Columbidae) in Zaria, Nigeria. Continental Journal of Biological Sciences 1: 1-9.

6. Kobayashi K, Kumakura M, Yoshimura K, Inatomi M, Asami T, et al. (1998) Fine structure of the tongue and lingual papillae of the penguin. Arch Histol Cytol 61: 37-46.

7. Jackowiak H, Godynicki S (2005) Light and scanning electron microscopic study of the tongue in the white tailed eagle (Haliaeetus albicilla, Accipitridae, Aves). Ann Anat 187: 251-259.

8. Jackowiak H, Skieresz-Szewczyk K, Godynicki S, Iwasaki S, Meyer W, et al. (2011) Functional morphology of the tongue in the domestic goose (Anser anser f. domestica). Anat Rec (Hoboken) 294: 1574-1584.

9. Erdogan S, Pérez W, Alan A (2012) Anatomical and scanning electron microscopic investigations of the tongue and laryngeal entrance in the longlegged buzzard (Buteorufinus, Cretzschmar, 1829). Microsc. Resesarch. Technique 75: 1245-1252.

10. Vollmerhaus B, Sinowatz F (1992) Verdauungsapparat. In: Nickel R, Schummer E, Seiferle E (edn.) Anatomie der Vögel Bd. 5. Lehrbuch der Anatomie der Haustiere, Parey.

11. Komarek V, Malinovesky L, Lemez L (1986) Anatomia avium domestica rumet embryologiagalli. Prirodavedavatel'stvoknih a casoposov, Bratyslava.

12. Emura S, Chen $\mathrm{H}$ (2008) Scanning electron microscopic study of the tongue in the owl (Strix uralensis). Anat Histol Embryol 37: 475-478

13. Emura S, Okumura T, Chen $\mathrm{H}$ (2009) Scanning electron microscopic study of the tongue in the Japanese Pygmi Woodpecker (Dendrocoposkizuki). Okajimas Folia Anat Jpn 86: 31-35.

14. Parchami A, Fatahian Dehkordi RA, Bahadoran S (2010) Fine Structure of the Dorsal Lingual Epithelium of the Common Quail (Coturnixcoturnix). World Applied Sciences Journal 10: 1185-1189.

15. Jackowiak H, Andrzejewski W, Godynicki S (2006) Light and scanning electron microscopic study of the tongue in the cormorant Phalacrocorax carbo (Phalacrocoracidae, Aves). Zoolog Sci 23: 161-167.
16. Jackowiak H, Ludwig M (2008) Light and scanning electron microscopic study of the structure of the ostrich (Strutio camelus) tongue. Zoolog Sci 25: 188-194.

17. Emura S, Okumura T, Chen $\mathrm{H}$ (2008) Scanning electron microscopic study of the tongue in the peregrine falcon and common kestrel. Okajimas Folia Anat Jpn 85: 11-15.

18. Iwasaki S (1992) Fine structure of the dorsal lingual epithelium of the little tern, Sterna albifrons Pallas (Aves, Lari). J Morphol 212: 13-26.

19. Iwasaki S, Kobayashi K (1986) Scanning and transmission electron microscopy studies on the lingual dorsal epithelium of chickens. Kaibogaku Zasshi 61: 83-96.

20. Homberger DG, Brush AH (1986) Functional morphological and biochemical correlation of the keratinized structure in the African Grey parrot Psittacuserithacus (Aves).Zoomorphology 106: 103-114.

21. Klos H, Lang E (1982) Handbook of Zoo Medicine: Diseases and Treatment of Wild Animals in Zoos, Game Parks, Circuses and Private Collections. Von Nostrand Reinhold Company, New York.

22. Bancroft JD, Stevens A (1996) Theory and practice of histological techniques (4thedn), Churchill Livingston. Edinburgh, London and New York.

23. Cohen J (2002) Applied multiple regression/correlation analysis for the behavioral science. Taylor, Francis (3rdedn), Lawrence Erlbaum Associates, London.

24. Argyrous G (2005) Statistics for research; with a guide to SPSS. (2ndedn), Sage, London.

25. Campbell B, Lack E (1985) A Dictionary of Birds. Calton T, Poyser AD (eds.).

26. Emura S (2008) SEM studies on the lingual papillae and their connective tissue cores of the black kite (Milvusmigrans) (in Japanese). Med Biol 152: 43-47.

27. Homberger DG, Meyers RA (1989) Morphology of the lingual apparatus of the domestic chicken, Gallus gallus, with special attention to the structure of the fasciae. Am J Anat 186: 217-257.

28. Emura S, Okumura T, Chen $H$ (2008) SEM studies on the connective tissue cores of the lingual papillae of the northern goshawk (Accipiter gentilis) Kaibogaku Zasshi 83: 77-80.

29. Parchami A, Fatahian Dehkordi RA, Bahadoran S (2010) Scanning electron microscopy of the tongue in the golden eagle Aquila chrysaetos (Aves: Falconiformes: Accipitridae). World J Zool 5: 257-263.

30. McLelland J (1975) Aves digestive system. In: Getty R (eds.) Sisson and Grossman's the Anatomy of the Domestic Animals. Saunders Company Philadelphia, Toronto, London.

31. Kullaa-Mikkonen A, Hynynen M, Hyvönen $P$ (1987) Filiform papillae of human rat and swine tongue. Acta Anat (Basel) 130: 280-284.

32. Kullaa-Mikkonen A, Sorvari TE (1985) A scanning electron microscopic study of the dorsal surface of the human tongue. Acta Anat (Basel) 123: 114-120.

33. McLelland J (1990) A Colour Atlas of Avian Anatomy. Wolfe Publishing Ltd.

34. El-Bakary NE (2011) Surface Morphology of the Tongue of the Hoopoe (UpupaEpops). Journal of American Science 7.

35. Grant V, Temeles EJ (1992) Foraging ability of rufous humming birds on humming bird flowers and hawkmoth flowers. Proc Natl Acad Sci USA 89: 9400-9404.

36. Iwasaki S, Asami T, Chiba A (1997) Ultrastructural study of the keratinization of the dorsal epithelium of the tongue of Middendorff's bean goose, Anser fabalis middendorffii (Anseres, Antidae). Anat Rec 247: 149-163. 